\title{
The Uprising of POW/MIA Wives: How Determined Women Forced America, Hanoi, and the World to Change
}

Steven L. Smith

Wayland Baptist University

\begin{abstract}
In the fall of 1966, a small and informal group of wives whose husbands were classified as Prisoner of War (POW) or Missing in Action (MIA) formed a small and informal group. By December 12, 1969, this group of women had gained such power, influence, and a multitude of disparate followers that twenty-six met with President and Mrs. Pat Nixon at the White House. In part, the POW/MIA story is about a small group of women taking a decisive role to change the United States POW/MIA policy, accentuate the plight of the prisoners, and demand humane treatment by Hanoi-all in a national and global arena.
\end{abstract}

\section{Introduction}

The war in Vietnam was tremendously divisive not only among American citizens, but also among other democratic and communists nations. Demonstrations against the war, both peaceful and violent, were part of the American fabric in the late 1960s. Military personnel were subject to public scorn and viewed by the citizenry with contempt for their service in Vietnam. To use the trite phrase that the war in Vietnam was not a "popular war" fails to convey the seething national hostility and unrest of the era. However, by the late 1960s, the POW/MIA issue had become a national unifying cause that culminated in Operation Homecoming in FebruaryMarch of 1973.

At the time, the United States Department of State was responsible for handling all POW/MIA matters, not the Department of Defense (Davis, 2000; Rochester \& Kiley, 1998). Furthermore, with the escalation of the air war over North Vietnam, the United States 
Department of State did not plan for, nor possess, a cogent strategy for dealing with POW/MIA matters. This negligence and oversight placed family members of POWs/MIAs in a perpetual state of limbo while the historical record demonstrates lack of direction due to interagency conflict between the Department of State and Department of Defense in addressing the POW/MIA matter directly.

\section{Cultural Context for Women in the mid to late 1960s}

Even though the roles of women were dramatically changing in the 1960s, POW/MIA wives were products of the 1950s persona of women and family. In part, this meant the women would fulfill the generational expectation to stay at home and raise the children while husbands went to work. As wives of military officers, however, they often thought of themselves and their husbands as inseparable from a career standpoint. This symbiotic career mindedness established a significant sense of patriotism and a clear understanding of the risks involved with military service.

An unintentional consequence of such a traditional mindset, however, manifested itself when the wives received official notification of their husband's imprisonment or MIA status. Richard Capen, Deputy Assistant Secretary of Defense for Public Affairs during the Nixon Administration, noted that this dual element of career and culture made the wives "hesitant to say a lot because they didn't know whether it was going to help get information on their husbands or whether it would hurt their lives" (personal communication, August 12, 2003). Due to their developing situation and fluctuating circumstances, a few of the POW/MIA wives would make the transformation from being a silent citizen to a public figurehead within the policy arena. The transformative process was often painful because they often found themselves in uncomfortable 
public or political situations. However, it was during this process of becoming activists that they would undertake various activities on behalf of the POWs/MIAs.

\section{American Governmental Policy for Matters of POW/MIA Wives}

The policies and procedures directed at the POW/MIA wives were reflective of the Department of State's policy of Quiet Diplomacy. The intended strategy was to use diplomatic pressure on the North Vietnamese through various back channels to handle POW/MIA matters. Melvin Laird, President Nixon's Secretary of Defense, called this strategy the "Do Nothing" policy (personal communication, June 14, 2003). From the perspective of the POW/MIA wives, this represented an attempt to curtail their access to the media and an effort to keep them from acting on their husbands' behalf. From 1965 to 1967, there was a fear that, if they did speak out, it would bring severe harm or hardship to the men and impair diplomatic efforts with Hanoi.

This fear of speaking out was legitimate. As noted in Smith (2006), the seventeen wives with whom I spoke recalled that, as part of the official notification process, military representatives conveyed specific instructions or guiding principles intended to govern their conversations and actions. Although details differed somewhat from person to person, more than one of the wives mentioned they received the following instructions, verbal or written, as part of the notification process:

- Keep quiet [about the status of your husband, knowledge of inhumane treatment, etc.]

- Don't talk about your husband's status

- Don't tell anybody

- Never talk to the press or give interviews

- Don't tell anyone about your circumstance

- Show any mail from your husband to the [military authorities]

- Never intercede in any way on behalf of the prisoner-it might disturb what the government is doing. (Later the guidance was amplified to specify "without State Department approval" and "independent actions could seriously damage negotiations being conducted in behalf of the prisoner by the State Department") 
In spite of the preposterousness of the official instructions given, the untended result was that among the wives there was a solidification of a shared experience, which fostered a group identity (Tee, Paulsen, \& Ashkanasy, 2013) and cohesion (Shay, 1994).

The misguided policy of "Quiet Diplomacy" was single-handedly changed by Secretary of Defense, Melvin Laird. In a public speech on March 1, 1969, Laird directly confronted the plight of the prisoners and the right of the family to know their husbands status. Laird's decision was directly connected to the relationships he developed with POW/MIA wives while he was a Congressman (personal communication, June 14, 2003). His actions, in turn, led senior military officials to argue aggressively for governmental policies to influence world opinion against Hanoi via counterpropaganda efforts while also advocating that public officials use public occasions to speak about the plight of prisoners and the governments overall concern for POWs and the accounting of MIAs.

\section{Going Public}

The first challenge for the wives was disregarding the early governmental prohibition from knowing the names of other military wives or family members in the same circumstance. By the fall of 1969, however, not only did they have a highly influential and powerful national organization, but in a memorandum to the President's Chief of Staff H. R. Haldeman dated October 20, 1969, Harry S. Dent, Deputy Counsel and Special Counsel to the President, indicated that he recently had seen news reports about the POW wives. He wrote: "These ladies have the sympathy of just about everybody these days."

The "Going Public" campaign, which included the Department of Defense, the White House, and certain members of Congress, was a well-orchestrated and planned event that was the culmination of POW/MIA wives developing a powerful and broad-spectrum base of support. 
Initially, the wives formed a support group patterned after naval aviation squadron wives groups. Without being granted official permission by military authorities, they sought and located other POW/MIA wives and encouraged the formation of local groups, which eventually were all interconnected via communication outlets of the day: letters, telegrams, and telephone. Out of these meetings came local and national strategies to include letter writing campaigns, interviews by various media outlets, public speaking at civic organizations, personal visits to elected and appointed officials, meetings with international leaders, and constant pressure via a number of means on elected and appointed officials for action on the POW/MIA matter.

The earliest strategy the wives developed was their message, which afforded them as a group a consequential level of influence over political leaders as well as their followers (Burak \& Bashshur, 2013). A unique feature of their message was that it was consistent and uniform within the National League of Families, the numerous auxiliary groups that formed around the League, and within the government's official "Go Public" campaign. Nowhere can this best be illustrated than Sybil Stockdale's Today show interview with Barbara Walters on January 20, 1970. Twice during the interview, Sybil referred to the "desperate plight of the prisoners," and that the goal of the organization was "[T]o secure the protection of the Geneva Convention Relative to the treatment of Prisoners of War. Sybil also identified the target audiences for the group's message, namely Congress, the American public, the citizens of the world, and the North Vietnamese government itself. She predicted that members of Congress "will become much more personally aware of how desperate the plight of all the men is." The initial sympathetic followers were mostly extended family members, neighbors, coworkers, friends from churches or synagogues, and civic groups — but that changed through persistence and gaining a growing cohort of followers. 


\section{Key Elements of Gaining Followers and Support}

Because the POW/MIA matter was inextricably linked to American wartime policy, it required the wives to engage elected officials and to have them, in turn, take on a dual role of following and leading. The wives influence tactics were initially a series of improvisations that transformed into intentional and strategic undertakings (Uhl-Bien, Riggio, Lowe, \& Carsten, 2014). Senator Bob Dole (R-KS) singlehandedly solicited the support of his colleagues in the Senate to use their voice via the Senate floor and Congressional Record to public highlight the POW/MIA matter. Additionally, he arranged and coordinated a bi-partisan tribute for the POWs in Constitutional Hall on May 1, 1970. An early and concerned advocate for POW/MIA matters was Senator Robert Kennedy (D-NY) who "urged" Averell Harriman, Department of State's Ambassador-at-Large for POW matters, "on to greater effort." Congressman Olin Teague (DTX) used his influence to ensure that the Dallas media covered several POW/MIA wives first and second trips to Paris where they confronted the North Vietnamese diplomatic authorities. Senator Hugh Scott (R-PA) echoed many of the National League themes in speeches regarding the plight of the prisoners, accountability of POWs and MIAs by Hanoi, lack of communication between prisoners and families, violations of the Geneva Convention, and even the accusation of possible murder. On the floor of the Senate, Senator Charles Goodell (R-NY) referred to how the POW and MIA matter had gained unanimous support among Americans who demanded justice even though the war created division in the country. Senator William Proxmire (D-WI) used time on the Senate floor to request support for Republican Senator Robert Dole's Constitutional Hall tribute. Governor Ronald Reagan (R-CA) provided Sybil Stockdale with his personal phone number when the wives might need his direct advocacy or intervention. These examples are miniscule but are representative of how numerous elected officials - at the national and state 
level—were undertaking the POW/MIA matter. Though not an elected official, the highly visible and engaged activist Ross Perot personally financed numerous massive global campaigns that gained enormous political and media attention. Perot understood the underlying political game that some played and was willing to use his financial resources to influence and bring pressure to bear on fence sitting politicians. A high level Nixon White House official said that he was assigned the job to "handle Ross" because some considered him a "madman" on the POW/MIA matter and wanted to limit his access to the President. When I told Mr. Perot about this arrangement, he slapped his knee and burst into laughter saying it was all part of a planned role to keep pressure on Nixon. He expressed no regrets playing the part of the court jester if it resulted in the prisoners' humane treatment, eventual release, and an accounting for the MIAs.

One vital aspect of gaining followers and their support was the serendipitous creation and development of the National League of Families, which was officially incorporated on June 30, 1970. The League itself is a study in innovation, creativity, necessity, spontaneity, and improvisation. As POW wife, Phyllis Galanti noted the wives were "slow" and "neophytes" when it came to comprehending the League's acquisition of power and understanding how best to use it (personal communication, April 26, 2003). Much of the lesson, however, was via trial and error.

It is impossible to determine precisely how many National League members there were at any given time because records, files, and historical documents of the National League have been lost. The only estimate of the size of the membership comes from a January 30, 1969 memorandum from Colonel Hughes, Armed Forces Aide to the President, to John D. Erlichman, Assistant to the President for Domestic Affairs. The memo from Hughes estimated that the 
number of women who were members of the National League at 50. Sybil Stockdale, however, put the estimated membership numbered around 60. By design, membership was quite small, initially restricted to wives of POWs and MIAs, later, to mothers and fathers of POWs and MIAs, and eventually to other family members. When Sybil Stockdale discussed the reasons why the League and National League became so influential, she cited the restrictive membership as one of the most significant components of the organization's success. She added, "We never had anybody that was not related in some way to a POW or MIA. It was strictly a family organization" (personal communication, June 8,2000). The intent was to ensure that formal members were committed to resolving the POW and MIA issue and to ensure that the story the organization told was a compelling one, i.e., a highly personal one.

\section{Utilizing a Plethora of Followers and Permitting Them Their Own Strategies}

When a young man approached Sybil Stockdale who wanted to participate in the POW/MIA cause, Sybil would not yield on the issue of limiting membership to family members. Instead, she invited the young man to her house in Coronado, and they jointly created a plan to form an affiliated organization, Concerned Citizens of America. This organization eventually became one of the many informally affiliated organizations that non-family members interested in working on the POW and MIA issue could join.

The close working relationship evidenced between the League of Wives (later the National League of Families) and Concerned Citizens of America was duplicated with other organizations. One such group was United We Stand, an organization formed by Ross Perot to publicize and generate public support for the POW issue. Another group was VIVA (Voices in Vital America). VIVA was important because it generated the idea of selling POW and MIA bracelets. Each bracelet was a simple metal band that contained the name and rank of a POW and 
the date on which he had been shot down. Carol Bates Brown, co-founder of VIVA, gave this historical account: "The idea for the bracelets was started by a fellow college student, Kay Hunter, and me, as a way to remember American prisoners of war suffering in captivity in Southeast Asia." The POW and MIA bracelets quickly became one of the most visible symbols of the plight of the POWs and MIAs.

A final example of organization instrumental in conveying the message of the National League was the Advertising Council. The Advertising Council is, as it was then, a private, nonprofit organization that produces public service announcements that addresses critical social issues to educate Americans and change public attitude. By early 1971, President Nixon and members of his administration played a role in encouraging the Advertising Council's POW campaign. From official White House documents, it is known that President Nixon met with Mr. Robert Keim, President of the Advertising Council, in early 1971. The Advertising Council's POW campaign was part of a more general strategy within the Nixon administration to use the POW and MIA issue to address a number of diplomatic and political goals.

\section{Conclusion}

Any discussion of external support via followers should not be seen, in any way, as minimizing the importance of the wives' and family members' efforts to get the POW issue onto government officials' agenda and into the consciousness of the American People. The POW wives were out in front on the POW issue; they were publicizing the POW issue before any of their external allies embraced it. Even before a national organization had been formed, and long before Senator Dole attempted to rouse his colleagues or Ross Perot attempted to influence President Nixon and the American public, the POW wives were making their personal visits and corresponding with government officials. 
Furthermore, even before the Advertising Council entered the picture, the wives had been working to generate publicity to "arouse the support of the American public" and have "local groups appeal to Congressman and Senators and government officials" (M. Winn, personal communication, 2003). The wives and the other family members who became part of the formal organization became quite adept at publicizing and applying pressure indirectly. In part, this was because they had a truly compelling personal story to tell. Sybil Stockdale was convinced that if the reality of the POW and MIA issue failed to touch the publics' soul it would not spread; therefore, according to Sybil, "the idea was to involve everyone emotionally" (personal communication, June 8, 2000).

Maybe this is precisely the lesson. By the time a group of representative POW/MIA wives and mothers met with President Nixon at the end of 1969, it was obvious that the group had achieved its goals of both obtaining the public's attention and placing the POW and MIA issue on government officials' radar screen. Moreover, even though the followers were slow in coming, they demonstrated the courage to serve a mutual purpose that caused the cessation of torture, inhumane treatment, and the eventual freedom of 591 prisoners.

\section{References}

Burak, O. \& Bashshur, M. R. (2013). Followership, leadership and social influence. The Leadership Quarterly, 24(6), 919-934.

Brown, C. B. (n.d.). Retrieved from the Vietnam Veterans Memorial-The Wall-USA. Retrieved from http://thewall-usa.com/bracelet.asp

Davis, V. E. (2000). The long road home: U.S. prisoners of war policy and planning in Southeast Asia. Washington, DC: Office of the Secretary of Defense.

Geneva Convention Relative to the Treatment of Prisoners of War. (1949). Diplomatic conference for the establishment of international conventions for the protection of victims 
of war. Geneva, Switzerland. Retrieved from the Library of Congress website: http://www.loc.gov/rr/frd/Military_Law/RC-Fin-Rec_Dipl-Conf-1949.html

National Archives and Records Administration, National Archives. (n.d.). Nixon Presidential Textual Materials, National Security-Defense-Prisoners-Files: White House Central Files: ND 18-3. College Park, MD. Retrieved from Nixon Presidential Library and Museum website: http://www.nixonlibrary.gov/forresearchers/find/textual/pow_mia/

National Archives and Records Administration, National Archives. (n.d.). Nixon Presidential Textual Materials, White House Special Files: Staff Member and Office Files. College Park, MD. Retrieved from Nixon Presidential Library and Museum website: http://www.nixonlibrary.gov/forresearchers/find/textual/special/smof/

National Archives and Records Administration, National Archives. (n.d.). Nixon Presidential Textual Materials, White House Central Files: Staff Member and Office Files. College Park, MD. Retrieved from Nixon Presidential Library and Museum website: http://www.nixonlibrary.gov/forresearchers/find/textual/central/staff_and_office.php

Rochester, S. I., \& Kiley, F. (1998). Honor bound: American prisoners of war in southeast Asia, 1961-1973. Annapolis, MD: Naval Institute Press.

Shay, Jonathan. (1994). Achilles in Vietnam: Combat trauma and the undoing of character. New York: NY: Simon and Schuster.

Smith, S. L. (2006). The reluctant sorority: Stories of American wives of Prisoners of War and Missing in Action, 1965-1973/lessons in exercising leadership in the absence of power (Doctoral Dissertation). WorldCat. (OCLC 851586827)

Tee, E. Y. J., Paulsen, N. \& Ashkanasy, N. M. (2013). Revisiting followership through a social identity perspective: The role of collective follower emotion and action. The Leadership Quarterly, 24(6), 902-918.

Uhl-Bien, M, Riggio, R. E., Lowe, K. B., \& Carsten, M. K. (2014). Followership theory: A review and research agenda. The Leadership Quarterly, 25(1), 83-104.

\section{Author Biography}

Steve Smith served in the United States Navy and Marine Corps from 1984 to 2006, which included seven operational commands and staff tour at Navy Warfare Development Command. $\mathrm{He}$ is the author of the first naval warfare publication on religious ministry and assisted with major revisions to the joint warfare publication on the same subject. He was also on a select committee to draft joint military policy on detainee matters. He holds degrees from Grand Canyon College, Southwestern Baptist Theological Seminary, United States Marine Corps War College, Command and Staff School, and University of San Diego. He is currently the Executive 
Director of Wayland Baptist University, Albuquerque and Associate Professor, Business and Education. 